Original Research Paper

\title{
Damage Control of Liquid Waste Pumping Machines in Palm Oil Companies
}

Agustina Hotma Uli Tumanggor ${ }^{1 *}$, Akhmad Syarief ${ }^{2}$, Fendy Ari Atmana²

${ }^{1}$ Program of Industrial Engineering, Faculty of Sains and Technology, Sari Mulia University. Banjarmasin, Indonesia.

${ }^{2}$ Program of Mechanical Engineering, Faculty of Engineering, Lambung Mangkurat University. Banjarmasin, Indonesia.

\section{Article History}

Received:

30.09.2021

Revised:

28.10.2021

Accepted:

17.12.2021

*Corresponding Author:

Agustina Tumanggor

Email:

agustina.hotma@gmail.com

This is an open access article, licensed under: $\mathrm{CC}-\mathrm{BY}-\mathrm{SA}$
Abstract: PT. X is a company that works in the field of oil palm plantations and has a palm oil production capacity of 60 tons per hour. The products of palm oil that have been produced are Crude Palm Oil (CPO) and Palm Kernel Oil (PKO). The various kinds of waste produced by the company as a result of the palm oil industry process are liquid waste, palm kernels, fiber and seed shells. Liquid waste is used as organic fertilizer for oil palm plantations which will be sent through a liquid waste pump machine. Damage that occurs to the liquid waste pump machine will inhibit the delivery of liquid waste to the plantation, thus affecting the yield of palm oil from the plantation itself. This study describes the application of repair and preventive maintenance policies for liquid waste pump machines by looking at the frequency of damage to the liquid waste pump engine and predicting the delivery of liquid waste to the pump engine for the next period as well as providing solutions for handling damage that occurs in the liquid waste pump engine. From the results of calculations on data processing, the results of how to control the causes of damage that occur in the liquid waste pump machine can be overcome by using the Preventive Maintenance Method within a period of 1 month and maintenance of every component in the liquid waste pump machine within 1 cycle, namely 357.27 hours with a repair time of 5.82 hours. Controlling other causes of damage is to add a filter to the liquid waste pool so that stones, leaves and liquid waste husks do not hinder the suction pipe of the liquid waste pump machine.

Keywords: Industrial Maintenance System, Reliability, Weibull Distribution. 


\section{Introduction}

Palm oil is one of the plantation commodities that provide benefits and hope to improve the country's and regional economy from the non-oil and gas sector [1] [2] [3]. The prospect of development and economic value generated from the oil palm plantation business has been able to contribute in improving the community's economy. The resulting product is in the form of Crude Plam Oil (CPO) vegetable oil which is a raw material for the food industry, pharmaceutical industry, cosmetics and so on [4].

Palm oil productivity can produce up to 6 tons/ha of oil, meanwhile, other vegetable oil sources such as coconut, soybean, and olive only produce less than 4.5 tons/ha. The part of the oil palm plant that has high economic value is the fruit that is arranged in a bunch called fresh fruit bunches (FFB). The part of the oil palm fruit in the flesh or mesocrap produces CPO oil as much as $20 \%-24 \%$. Meanwhile, the core produces Plam Kernel Oil (PKO) as much as 3\%-5\% [5].

The results of CPO and PKO from a fresh fruit bunch of oil palm require various stages of the process, where the process is carried out at the Palm Oil Mill (PKS). There are so many various companies in Indonesia that focus on business in the palm oil sector, one of which is the PT. X. is located at Batu Ampar Mill, Kotabaru, in South Kalimantan. Palm oil mills also produce solid and liquid waste. An industrial company is required to properly manage the industrial waste so as not to pollute the surrounding environment. Waste generated from palm oil companies, among others, is stump, shell, fiber, solid, and liquid waste [6].

Palm oil liquid waste consists of water from boiling oil palm which can be used as organic fertilizer in oil palm plantations. Liquid waste will be sent to oil palm plantations using a liquid waste pump machine, therefore the liquid waste pump machine is one of the main components in the process of sending liquid waste to oil palm plantations as organic fertilizer.

One of the inhibiting factors in the process of sending liquid waste using a pump engine is the occurrence of damage to the liquid waste pump engine itself caused by various internal and external factors. This study aims to control the damage to the liquid waste pump machine in palm oil co

Production planning is an activity to determine the product to be produced, the quantity needed, when the product must be completed and the required sources. Production control is an activity that determines the ability of the resources used to fulfill the plan, the ability of production to run according to plan, make improvements to the plan. So it can be concluded that production planning and control is planning production activities so that what has been planned can be carried out properly [7].

The definition of production planning and control above can be concluded that a company is required to have good industrial planning and control so that a company gets maximum, efficient and effective production results [8]. The various functions of production planning and control are as follows:

1. Forecasting product demand expressed in terms of product quantities as a function of time.

2. Monitor actual demand, compare it with previous demand forecasts and revise the forecast if deviations occur.

3. Determine the size of an economical order for raw materials to be purchased.

4. Establish an economical inventory system

5. Determine production requirements and inventory levels at a given time.

6. Monitor inventory levels, compare them with inventory plans and revise production plans at specified times.

7. As well as making a detailed production schedule, assignment and loading of machines and labor.

From the various production planning and control functions above, if applied to the palm oil industry company, the company must know and predict how palm oil production will be today and in the future by paying attention to the oil palm fruit season itself and how to overcome what if there is a lack of oil palm fruit entered for production by the company. Talking about palm oil industry companies, not only PKO and CPO are produced, but there is also waste that is the result of the palm oil industry process itself, one of which is liquid waste produced.

One oil palm tree itself requires 20-30 liters of water for its daily needs. If the oil palm lacks water, it will result in the production of oil palm fruit, therefore the season for the abundance of oil palm fruit will usually occur during the rainy season and vice versa. Liquid waste from the production of oil palm itself can be used as organic fertilizer which is good for the oil palm plant itself and oil palm 
plants can get enough water from the liquid waste used. So the liquid waste functions as fertilizer and also as a water supply for the daily water needs of the oil palm plant itself.

In the process of using liquid waste for oil palm plantations, it takes a long process so that liquid waste is safe for plantations and the environment itself, which takes 60 days to be stored in liquid waste ponds, where each pond is $100 \mathrm{~m}$ long, 25 wide. The depth of the pool is $4 \mathrm{~m}$ with a maximum volume of $10000 \mathrm{~m} 3$ for each pond. PT. X has six liquid waste collection ponds that are actively used and two liquid waste ponds that are not actively used. After being collected, the liquid waste will be sent to the plantation using a pump machine through pipes with a diameter of 6 inches.

\section{Literture Review}

\subsection{Pumping Machines Used in Liquid Waste Delivery Ponds}

PT. X is a branch company that works in the plantation and food sector. PT X has a maximum FFB processing capacity of 60 tons per hour which can produce liquid waste of approximately $60 \%$ of its FFB processing capacity per hour [9]. This causes the company to be able to take advantage of how the liquid waste produced can be used as well as possible by making the liquid waste as organic fertilizer for oil palm plantations owned by PT. X so that oil palm plantations can produce maximum fruit and good quality. The daily requirement of liquid waste used for oil palm plantations to meet the needs of organic fertilizer is approximately $500 \mathrm{~m}^{3}$.

PT. X has six active pools and two inactive pools, each of which has a length, width and height of $100 \mathrm{~m} \times 25 \mathrm{~m} \mathrm{x} 4 \mathrm{~m}$ to accommodate $10,000 \mathrm{~m}^{3}$ of liquid waste produced. Liquid waste will be accommodated in available waste ponds for a period of 60 days in order to meet the standards for the use of organic fertilizers and not pollute the environment around oil palm plantations. Liquid waste that is ready to be sent to oil palm plantations will be channeled through irrigation channels to a liquid waste delivery pond with a length, width and height of $3 \mathrm{~m} \times 3 \mathrm{~m} \times 2 \mathrm{~m}$ with a $1 \mathrm{~m}$ high barrier inside. The barrier functions as a barrier so that it is easy to clean the liquid waste input pipe when there is inhibition by leaves or liquid waste husks [10].

In the liquid waste delivery pond there are two centrifugal pump machines with the specifications of each machine, namely $55 \mathrm{~kW}$ as the number one pumping machine and $30 \mathrm{~kW}$ as the number two pumping machine.

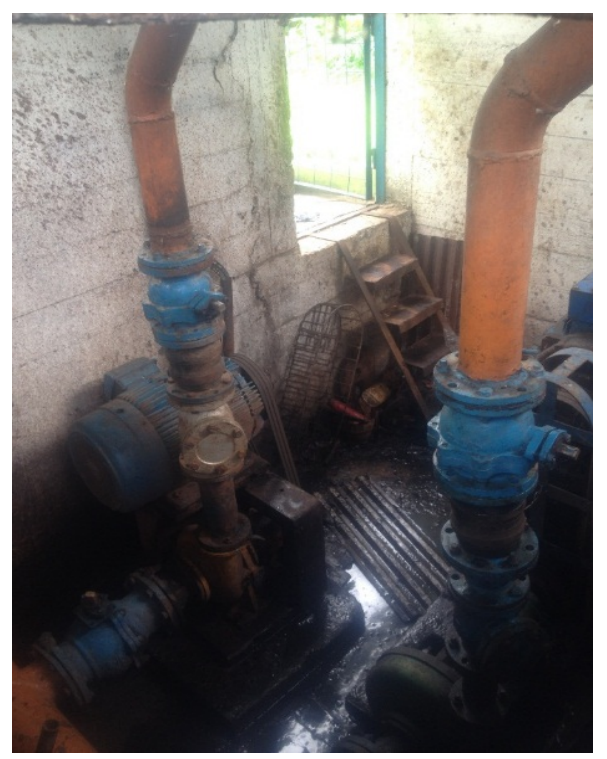

Figure 1. Liquid Waste Centrifugal Pump Machine

The maximum pressure in the fluid flow that occurs in the centrifugal pump machine is not more than 15 bar, this is in order to extend the service life of the liquid waste centrifugal pump machine component. 


\subsection{Linear Regression Method}

In delivering liquid waste to oil palm plantations using a pump engine that has a specification of $30 \mathrm{~kW}$ engine power and the type of pump used is a Centrifugal pump. The delivery of liquid waste to oil palm plantations will be related to the available liquid waste, therefore predicting the state of liquid waste for the next period needs to be done in order to find out whether the pumping machine can perform its maximum performance on the delivery of liquid waste carried out [11]. Liquid waste forecasting can be done using the Linear Regression Method [12]. The formula for linear regression is as follows:

$$
\begin{aligned}
& Y=a+b x \\
& a=\frac{\sum X Y-b \sum x}{n} \\
& b=\frac{n \sum X Y-\sum X\left(\sum X Y\right)}{n \sum X^{2}-\left(\sum X^{2}\right)}
\end{aligned}
$$

where,

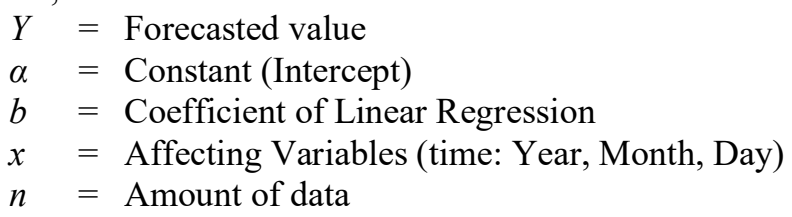

\subsection{Repair Policy Method}

The Repair Policy method is a maintenance system that is carried out when a breakdown occurs [13]. This method can be searched using the following formula:

$$
\begin{aligned}
& T C r=B \cdot C r \\
& B=\frac{N}{T b} \\
& T b=\sum_{v}^{n} p i \cdot T i
\end{aligned}
$$

where,

$T C r=$ Expected cost of repair

$B=$ Average number of breakdowns per month for $\mathrm{N}$ tools per machine

$\mathrm{Cr}=$ Cost of repairs

$T b=$ Average runtime per tool before crash

$N=$ Number of tools or machines

\subsection{Methods of Preventive Maintenance Policy}

The Preventive Maintenance Policy method is a maintenance system that is carried out on a scheduled basis without waiting until a machine is damaged [14] [15]. This method can be searched using the following formula:

$$
\operatorname{TMC}(n)=\operatorname{TCr}(n)+\operatorname{TCm}(n)
$$

where,

$T M C(n)=$ Total cost of maintenance per month

$\mathrm{TCr} \quad=$ Repair fee per month

$\mathrm{TCm} \quad=$ Monthly preventive maintenance costs 
The steps to be taken are as follows:

1) Calculate the expected cumulative breakdown number of breakdowns (Bn) for all machines during the preventive maintenance period $(\mathrm{Tp}=\mathrm{n}$ weeks)

2) Determine the average number of breakdowns per month (B) as a ratio of $\mathrm{Bn} / \mathrm{n}$

3) Estimated repair costs per month:

$$
\operatorname{TCr}(n)=\left(\frac{B n}{n}\right) C r
$$

4) Estimated preventive maintenance costs per month:

$$
\operatorname{TCn}(n)=\frac{N \cdot C m}{n}
$$

5) Total cost of maintenance: $\mathrm{TMC}(\mathrm{n})=\mathrm{TCr}(\mathrm{n})+\mathrm{TCm}(\mathrm{n})$

\subsection{Cumulative Distribution Function}

The Cumulative Distribution Function (CDF) is a function that adds up the probability values to a certain event as already known the number of possible values is 1 . The use of CDF is to determine the probability (probability) in a random experiment [13]. CDF has the conditions that $0 \leq \mathrm{F}(\mathrm{t}) \leq 1$ and $\mathrm{F}(\mathrm{t})$ is a non-decreasing function (the function of the data is not monotonous/random data) while the $\mathrm{CDF}$ function is as follows:

$$
F(t)=1-e^{(t)}
$$

$$
\begin{aligned}
\text { where, } & \\
F(\mathrm{t}) & =\text { Cumulative Distribution Function (\%) } \\
t & =\text { time (hour) } \\
\theta & =\text { Parameter Shape of the Weibull Distribution } \\
\beta & =\text { Scale parameters of the Weibull Distribution }
\end{aligned}
$$

\subsection{Reliability}

The reliability function $R(t)$ is a reliability function to determine a component system or sub-system running according to its capabilities at a certain time. The functions of reliability are:

$$
R(t)=e^{-\left(\frac{t}{\rho}\right)^{\beta}}
$$

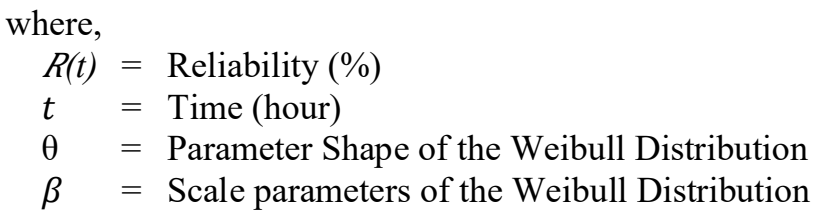

\subsection{Failure Rate}

The level of failure or the level of damage is the main requirement of a component item or subsystem which at certain intervals will fail. The functions of the failure rate are:

$$
h(t)=\frac{\beta}{\theta}\left(\frac{t}{\theta}\right)^{\beta-1}
$$

where,

$$
\begin{array}{ll}
h(\mathrm{t}) & =\text { Failure rate } \\
t & =\text { Time (hour) } \\
\theta & =\text { Parameter Shape of the Weibull Distribution } \\
\beta & =\text { Scale parameters of the Weibull Distribution }
\end{array}
$$




\subsection{Mean}

The average life time can be taken from the Weibull distribution using the following function:

$$
E(t)=\theta \mathrm{I}^{\prime}\left(1+\frac{1}{\beta}\right)
$$

where,

$$
\begin{array}{ll}
E(\mathrm{t}) & =\text { Average Life (hour) } \\
t & =\text { Time (hour) } \\
\theta & =\text { Parameter Shape of the Weibull Distribution } \\
\beta & =\text { Scale parameters of the Weibull Distribution } \\
\Gamma & =\text { Gamma function, taken from the Gamma Function Table }
\end{array}
$$

\section{Methodology}

The research location was conducted at PT. X Kelumpang Hilir District, Kotabaru Regency, and South Kalimantan Province. The data used in this study include primary data and secondary data, where primary data comes directly from the object of research while secondary data comes from journals and library books. The flow chart of the research carried out is shown in Figure 2.

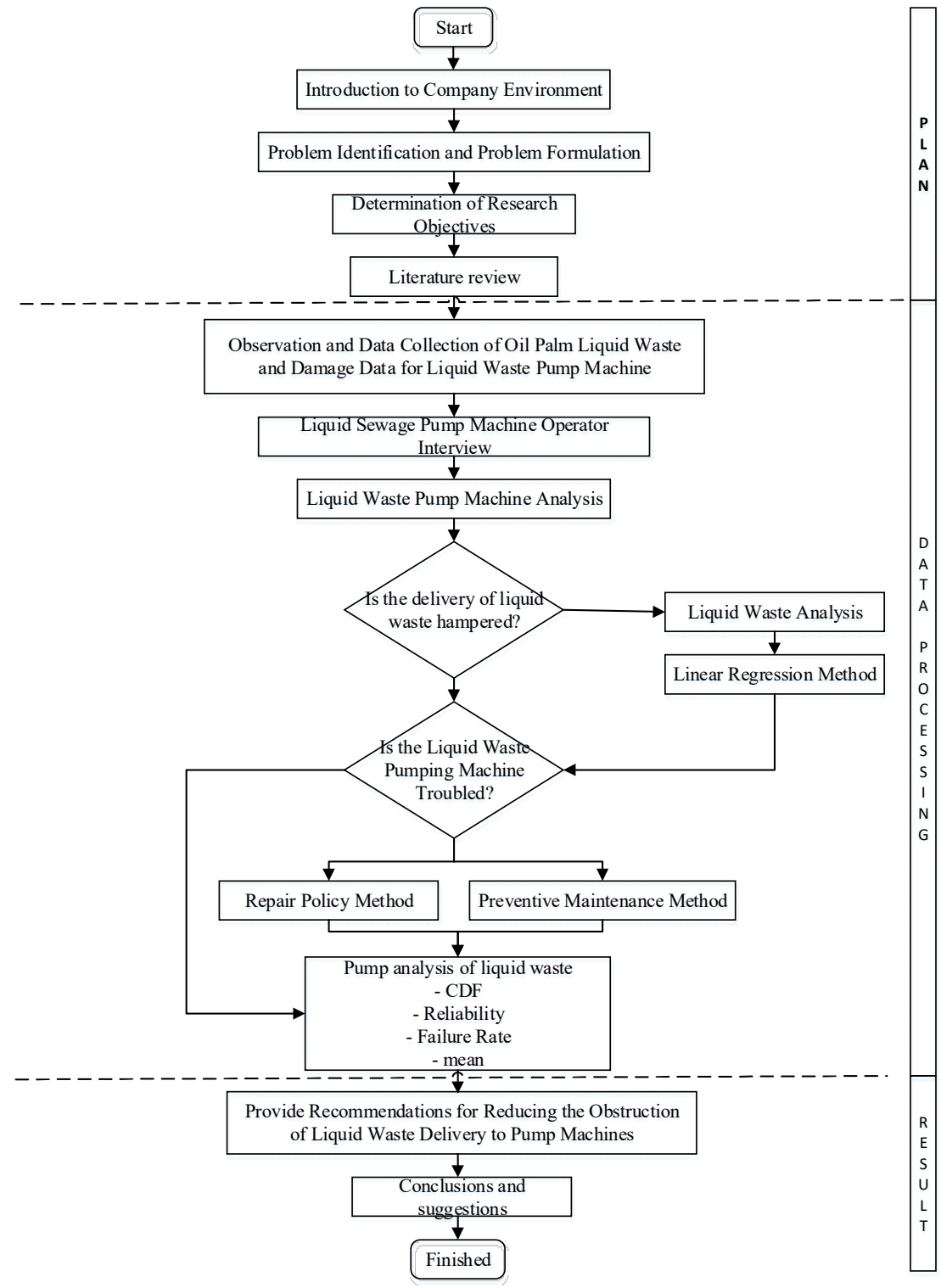

Figure 2. Research Method 


\section{Finding and Discussion}

In determining the forecasting of liquid waste in the next period, it is necessary to collect past data, namely data obtained when the research was carried out, data on liquid waste shipments obtained during the 45 days of the study are shown in Table 1 .

Table 1. Waste and FFB Delivery in the Production Process

\begin{tabular}{|c|c|c|c|c|c|c|c|}
\hline No & Date & TBS P & Output L & No & Date & TBS P & Output $\mathbf{~}$ \\
\hline 1 & $1 / 9 / 2015$ & 140 ton & 321 ton & 24 & $29 / 9 / 2015$ & 711 ton & 249 ton \\
\hline 2 & $2 / 9 / 2015$ & 591 ton & 206 ton & 25 & $30 / 9 / 2015$ & 733 ton & 305 ton \\
\hline 3 & $3 / 9 / 2015$ & 477 ton & 334 ton & 26 & $1 / 10 / 2015$ & 342 ton & 235 ton \\
\hline 4 & $4 / 9 / 2015$ & 455 ton & 318 ton & 27 & $2 / 10 / 2015$ & 488 ton & 185 ton \\
\hline 5 & $5 / 9 / 2015$ & 466 ton & 344 ton & 28 & $3 / 10 / 2015$ & 517 ton & 234 ton \\
\hline 6 & $7 / 9 / 2015$ & 746 ton & 346 ton & 29 & $5 / 10 / 2015$ & 670 ton & 225 ton \\
\hline 7 & $8 / 9 / 2015$ & 567 ton & 338 ton & 30 & $6 / 10 / 2015$ & 563 ton & 227 ton \\
\hline 8 & $9 / 9 / 2015$ & 524 ton & 522 ton & 31 & $7 / 10 / 2015$ & 586 ton & 228 ton \\
\hline 9 & $10 / 9 / 2015$ & 587 ton & 478 ton & 32 & $8 / 10 / 2015$ & 607 ton & 234 ton \\
\hline 10 & $11 / 9 / 2015$ & 537 ton & 296 ton & 33 & $9 / 10 / 2015$ & 538 ton & 186 ton \\
\hline 11 & $12 / 9 / 2015$ & 557 ton & 291 ton & 34 & $10 / 10 / 2015$ & 655 ton & 228 ton \\
\hline 12 & $14 / 9 / 2016$ & 768 ton & 121 ton & 35 & $12 / 10 / 2015$ & 742 ton & 122 ton \\
\hline 13 & $15 / 9 / 2016$ & 774 ton & 269 ton & 36 & $13 / 10 / 2015$ & 748 ton & 128 ton \\
\hline 14 & $16 / 9 / 2016$ & 640 ton & 224 ton & 37 & $15 / 10 / 2015$ & 806 ton & 83 ton \\
\hline 15 & $17 / 9 / 2016$ & 518 ton & 246 ton & 38 & $16 / 10 / 2015$ & 708 ton & 127 ton \\
\hline 16 & $18 / 9 / 2016$ & 491 ton & 177 ton & 39 & $17 / 10 / 2015$ & 756 ton & 249 ton \\
\hline 17 & $19 / 9 / 2016$ & 477 ton & 268 ton & 40 & $19 / 10 / 2015$ & 971 ton & 210 ton \\
\hline 18 & $21 / 9 / 2016$ & 896 ton & 277 ton & 41 & $20 / 10 / 2015$ & 998 ton & 244 ton \\
\hline 19 & $22 / 9 / 2016$ & 670 ton & 288 ton & 42 & $21 / 10 / 2015$ & 915 ton & 264 ton \\
\hline 20 & $23 / 9 / 2016$ & 611 ton & 290 ton & 43 & $22 / 10 / 2015$ & 903 ton & 220 ton \\
\hline 21 & $25 / 9 / 2016$ & 514 ton & 235 ton & 44 & $23 / 10 / 2015$ & 680 ton & 103 ton \\
\hline 22 & $26 / 9 / 2016$ & 550 ton & 277 ton & 45 & $24 / 10 / 2015$ & 946 ton & 45 ton \\
\hline 23 & $28 / 9 / 2016$ & 785 ton & 211 ton & & & & \\
\hline
\end{tabular}

Next is to perform forecasting calculations using the minitab application which can be seen in Figure 3.

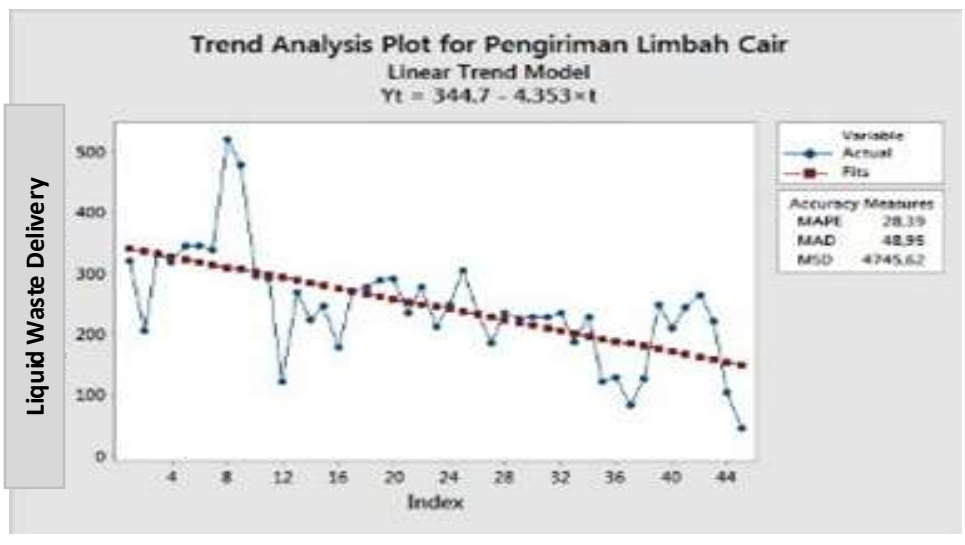

Figure 3. Linear Regression Graph

The results obtained using the Linear Regression Method are $\mathrm{Y}=344.7-4.353 \mathrm{x}$. By looking at the results of the calculation of Linear Regression with the Minitab Application, it can be predicted that the delivery of liquid waste in the next period, namely $\mathrm{x}=46$, is as follows:

$\mathrm{Y}=\mathrm{a}+\mathrm{bx}$

$$
=344,7+(-4,353 \times 46)
$$




$$
\begin{aligned}
& =344,7-200,238 \\
& =144,462 \mathrm{~m}^{3}
\end{aligned}
$$

\subsection{Data Analysis of Oil Palm Liquid Waste Pump Machine}

Damage to the liquid waste pump engine over a period of 41 months can be seen in Table 2 .

Table 2. Total Damage

\begin{tabular}{|c|c|}
\hline Period & Total Damage \\
\hline Maret 2021 & 1 \\
\hline Desember 2013 & 8 \\
\hline Februari 2014 & 1 \\
\hline Februari 2015 & 1 \\
\hline Maret 2015 & 4 \\
\hline
\end{tabular}

By looking at the damage that occurred, it can be seen in the Pareto diagram below where the most frequent damage in each year will be seen in Figure 4.

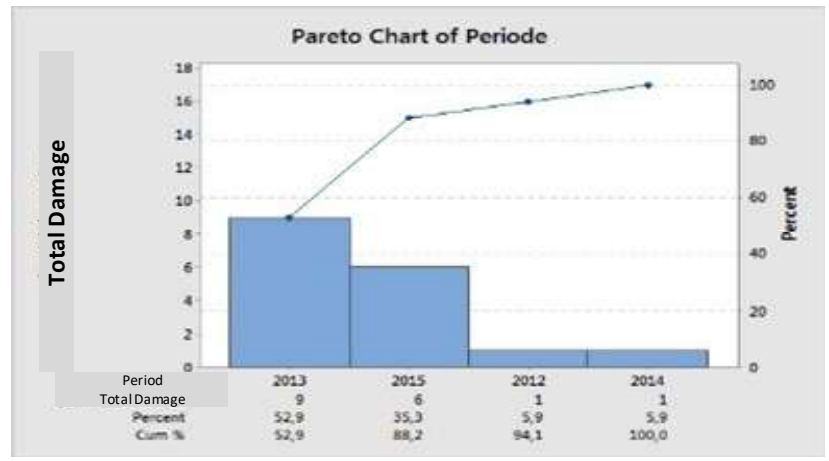

Figure 4. Pareto Diagram of Damage to the Pump Engine

It can be seen that the most damage occurred in 2013 which was 9 times. The percentage of damage that occurred during 41 months on the liquid waste pump machine can be seen in Table 3 below.

Table 3. Percentage of Damage

\begin{tabular}{|c|c|c|c|}
\hline No & Same Type of Damage & Total Damage & Damage Percentage \\
\hline 1 & Bearing & 3 & $17,65 \%$ \\
\hline 2 & Ball Vaalve & 2 & $11,76 \%$ \\
\hline 3 & Bolt Ring & 1 & $5,88 \%$ \\
\hline 4 & Bolts and Nuts & 3 & $17,65 \%$ \\
\hline 5 & Oil & 1 & $5,88 \%$ \\
\hline 6 & Glan Packing & 1 & $5,88 \%$ \\
\hline 7 & Shaft & 2 & $11,76 \%$ \\
\hline 8 & Mechanical Seal for Kew Pump & 1 & $5,88 \%$ \\
\hline 9 & O-Ring & 1 & $5,88 \%$ \\
\hline 10 & Pressure Gauge & 1 & $5,88 \%$ \\
\hline 11 & Wheel for Transfer Carriage & 1 & $5,88 \%$ \\
\hline & Total & 17 & $100 \%$ \\
\hline
\end{tabular}

\subsection{Determination of Repair Maintenance Costs}

The calculation of Repair Maintenance for the liquid waste pump machine is as follows:

1) The company's labor costs Rp. 7,511,- per hour, this calculation is obtained by using data on the average regional minimum wage of South Kalimantan during 2012, 2013, 2014 and 2015 
which is Rp. 1,502,125,- per month, where the company's working days in a month are 25 days and working hours are 8 hours.

2) The cost of the spare parts used is the cost of the components (parts) that are replaced.

3) The number of workers needed to repair the machine is 3 people, with 8 hours of repair time.

From the description above, it can be obtained:

$\mathrm{Cr}=\{($ Sparepart time to repair $\mathrm{x}$ amount of labor $\mathrm{x}$ labor cost per hour $)+$ material cost per spare part $\}$

$\operatorname{Cr}(1)=\{(8$ hours $\times 3$ persons $\times \operatorname{Rp~7,511~per~hour~})+\operatorname{Rp} 2,432,462\}=\operatorname{Rp} 2,612,717$ per breakdown.

\subsection{Estimated Repair Policy Cost}

The costs incurred in this repair policy are repair costs and downtime costs:

$\mathrm{TMC}($ Repair Policy $)=\mathrm{TCr}+\mathrm{TCd}$

Therefore, when the liquid waste pump engine is damaged, production does not stop, so the total cost of downtime does not exist $(\mathrm{TCd}=0)$. Before we determine $\mathrm{TCr}$, we must first calculate the average machine run-time (Tb), then calculate the average breakdown per month or B. The costs incurred in this repair policy are repair costs and downtime costs:

1) Repair Costs

$$
\mathrm{CR}_{1}=\operatorname{Rp} 2,612 / 717
$$

2) Average run-time per machine before Failure

$$
\begin{aligned}
T_{b} & =T_{1} p_{1}+T_{2} p_{2}+T_{3} p_{3}+\cdots+T_{41} p_{41} \\
& =1(0.06)+2(0)+3(0)+\ldots+41(2.41)=27 \text { months }
\end{aligned}
$$

3) Estimated Repair Policy cost per Downtime:

$$
\begin{aligned}
T C r_{1} & =\frac{N}{T_{b}} \cdot C r_{1}=\frac{1}{27} \times R p 2 \cdot 612 \cdot 727_{1}- \\
& =\operatorname{Rp} 96,767
\end{aligned}
$$

\begin{tabular}{|c|c|c|c|c|c|}
\hline No & $\mathrm{Cr}$ & \multicolumn{2}{|r|}{$\mathrm{TCr}$} & \multicolumn{2}{|r|}{ TMC } \\
\hline 1 & Rp 2.612.717 & $\mathrm{Rp}$ & 96.767 & $\mathrm{Rp}$ & 96.767 \\
\hline 2 & $\operatorname{Rp} 3.817 .705$ & $\mathbf{R p}$ & 141.396 & $\mathbf{R p}$ & 141.396 \\
\hline 3 & $\operatorname{Rp} 2.468 .513$ & $\mathrm{Rp}$ & 91.426 & $\mathrm{Rp}$ & 91.426 \\
\hline 4 & 51.051 & $\mathbf{R p}$ & 1.891 & $\mathrm{Rp}$ & 1.891 \\
\hline 5 & 56.051 & $\mathrm{Rp}$ & 2.076 & $\mathrm{Rp}$ & 2.076 \\
\hline 6 & 61.051 & $R p$ & 2.261 & $R p$ & 2.261 \\
\hline 7 & Rp 331.051 & $\mathrm{Rp}$ & 12.261 & $\mathrm{Rp}$ & 12.261 \\
\hline 8 & $\operatorname{Rp} 3.818 .860$ & $\mathbf{R p}$ & 141.439 & $\mathrm{Rp}$ & 141.439 \\
\hline 9 & Rp 103.160 & $\mathrm{Rp}$ & 3.821 & $\mathrm{Rp}$ & 3.821 \\
\hline 10 & 97.660 & $\mathbf{R p}$ & 3.617 & $\mathrm{Rp}$ & 3.617 \\
\hline 11 & Rp 3.321 .922 & $\mathrm{Rp}$ & 123.034 & $\mathrm{Rp}$ & 123.034 \\
\hline 12 & Rp 7.180 .255 & $\mathrm{Rp}$ & 265.935 & $R p$ & 265.935 \\
\hline 13 & Rp $\quad 320.264$ & $\mathrm{Rp}$ & 11.862 & $R p$ & 11.862 \\
\hline 14 & $\begin{array}{ll}R p & 908.721 \\
\end{array}$ & $\mathbf{R p}$ & 33.656 & $\mathrm{Rp}$ & 33.656 \\
\hline 15 & Rp $\quad 60.064$ & $R p$ & 2.225 & $R p$ & 2.225 \\
\hline 16 & $\begin{array}{ll}R p & 730.064 \\
\end{array}$ & $\mathrm{Rp}$ & 27.039 & $R p$ & 27.039 \\
\hline \multirow[t]{2}{*}{17} & \multirow{2}{*}{$\begin{array}{l}\text { Ro } 9.640 .255 \\
\text { Total }\end{array}$} & $\mathbf{R p}$ & 357.046 & $R p$ & 357.046 \\
\hline & & $\mathrm{Rp}$ & 1.317 .754 & $\mathrm{Rp}$ & 1.317 .754 \\
\hline
\end{tabular}

So, the estimated cost of Repair Policy per Towntime is

$$
\begin{aligned}
\mathrm{TMC}_{1}=\mathrm{TCr}_{1}+\mathrm{TCd} & =\operatorname{Rp} 96,767+\operatorname{Rp} 0 \\
& =\operatorname{Rp} 96,767
\end{aligned}
$$

For further calculation results can be seen in Table 4.

Table 4. Repair Policy Calculation Results

\subsection{Determining Preventive Maintenance Costs}

The calculation of preventive maintenance costs $(\mathrm{Cm})$ for each machine is as follows:

1) The company's labor cost is Rp. 7,511,-- per hour, this calculation is obtained by using the data on the average regional minimum wage of South Kalimantan during 2012, 2013, 2014 and 
2015 which is Rp. 1,502,125,- per month, where the company's working days in a month are 25 days and working hours are 8 hours

2) The number of workers needed to repair the machine is 3 people, with 8 hours of preventive time.

3) The preventive action taken is enough to clean the input pipe blockage and check every part of the liquid waste pump machine.

$\mathrm{Cm}=$ time for maintenance $\mathrm{x}$ amount of labor $\mathrm{x}$ labor cost per hour.

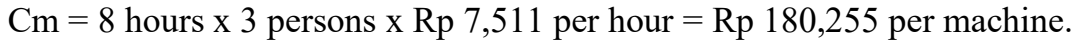

1) Estimated Cost of Preventive Maintenance Policy

Preventive Maintenance Policy for $\mathrm{n}=1$ month Preventive Maintenance Policy for $\mathrm{n}=1$ month

Estimated cumulative amount of damage $(\mathrm{B} 1)=\mathrm{Np} 1=1(0.06)=0.06$ damage per month

Average amount of damage per month $(B)=0.06$ damage per month

Estimated repair costs per month $\left(\mathrm{TCr}_{1}\right)=\mathrm{Rp} 153,689$ per month

Estimated preventive maintenance costs per month $\left(\mathrm{TCm}_{1}\right)=\mathrm{Rp} 180,255$ per month

Total maintenance cost per month $\left(\mathrm{TMC}_{1}\right)$

$\mathrm{TMC}_{1}=\mathrm{TCr}_{1}+\mathrm{TCm}_{1}=\mathrm{Rp} 153,689+\mathrm{Tp} 180,255=\mathrm{Rp} 333,944$.

2) Preventive Maintenance Policy for $\mathrm{n}=2$ months

Estimated cumulative amount of damage $\left(\mathrm{B}_{2}\right)$

$\mathrm{B}_{2}=\mathrm{N}(\mathrm{p} 1+\mathrm{p} 2)+\mathrm{B} 1 \mathrm{p} 1$

$=1(0.06+0)+0.06 \times 0.06=0.062$ damage per month

Average amount of damage per month $(\mathrm{B})=0.031$ damage per month

Estimated repair costs per month $\left(\mathrm{TCr}_{2}\right) \mathrm{TCr}_{2}=\mathrm{B} . \mathrm{Cr}_{2}=0.031 \times \mathrm{Rp} 0=\mathrm{Rp} 0$ per month

Estimated preventive maintenance costs per month $=$ Rp. 90,127 per month

Total maintenance cost per month $\left(\mathrm{TMC}_{2}\right)$

$\mathrm{TMC}_{2}=\mathrm{TCr}_{2}+\mathrm{TCm}_{2}=\mathrm{Rp} 0+\mathrm{Rp} 90,127=\mathrm{Rp} 90,127$ per month

For the calculation of Preventive maintenance policy $n=3$ months to $n=41$ months on the liquid waste pump machine can be seen the following Figure 5.

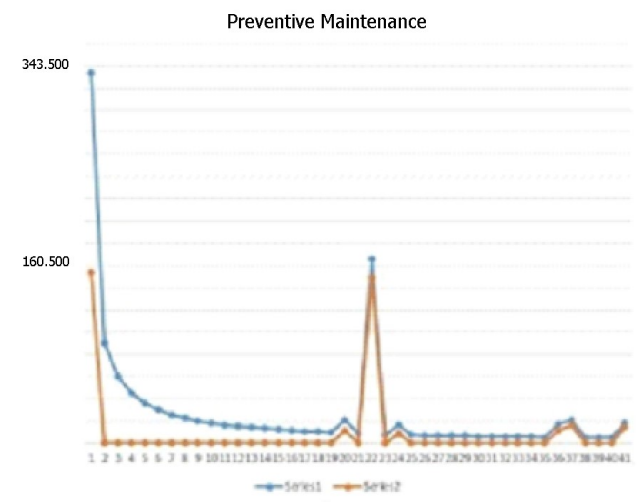

Figure 5. Preventive Maintenance Chart

\subsection{Life Time of Liquid Waste Pump Machine}

The Life Time of the liquid waste pump machine can be seen in the following Table 5 .

Table 5. Life Time of Liquid Waste Pump Machine 


\begin{tabular}{|l|l|l|l|}
\hline \multicolumn{4}{|c|}{ Life Time (in hours) } \\
\hline 497,22 & 461,97 & 354,18 & 193,39 \\
\hline 381,53 & 474,75 & 364,91 & 254,83 \\
\hline 384,79 & 429,25 & 342,76 & 338,53 \\
\hline 390,02 & 444,17 & 355,58 & 220,36 \\
\hline 348,68 & 453,47 & 346,29 & 206,63 \\
\hline 347,21 & 505,47 & 282,28 & 246,58 \\
\hline 316,07 & 569,97 & 231,47 & 322,49 \\
\hline 285,12 & 528,74 & 186,93 & 396,47 \\
\hline 339,50 & 488,39 & 172,16 & 372,97 \\
\hline
\end{tabular}

Results of the Weibull distribution can be seen in Figure 6 while the Weibull Distribution image is shown in Figure 7.

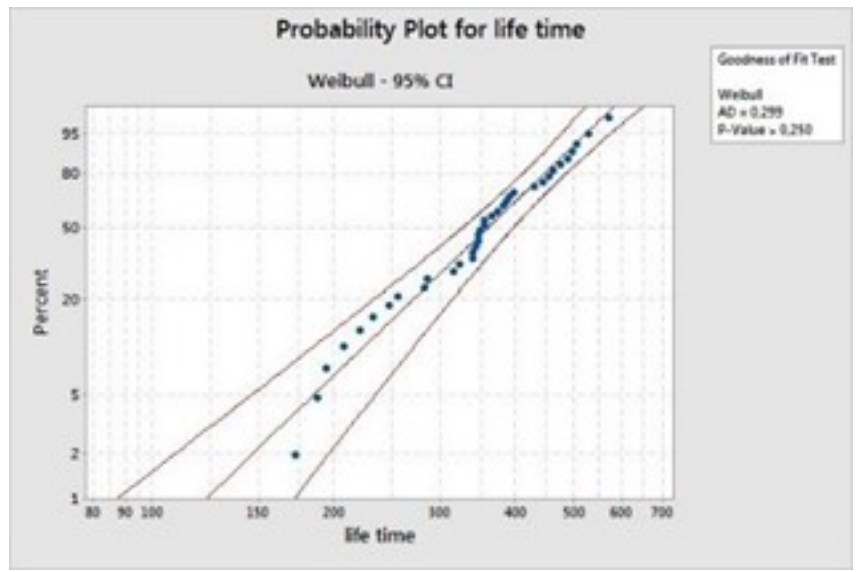

Figure 6. Weibull Distribution Plot Data Life Time Liquid Waste Pump Machine

From Figure 6, can be explained from the percentage of 95\% CI (Confidance Interval) is the range between two values where the value of a sample mean is exactly in the middle or one of the parameters used to measure how accurately the mean of a sample represents (includes) the mean value real population. The CI value can be expressed in terms of the probability that several samples in 100 times of sampling the population mean value will actually be included in a sample mean. For $95 \% \mathrm{CI}$ means that if I take a 100 sample data, then my 95 sample probability will include the true population mean value.

The Life Time data above is then processed into the Weibull Distribution and Identification Distribution using the Minitab 17.0 software.

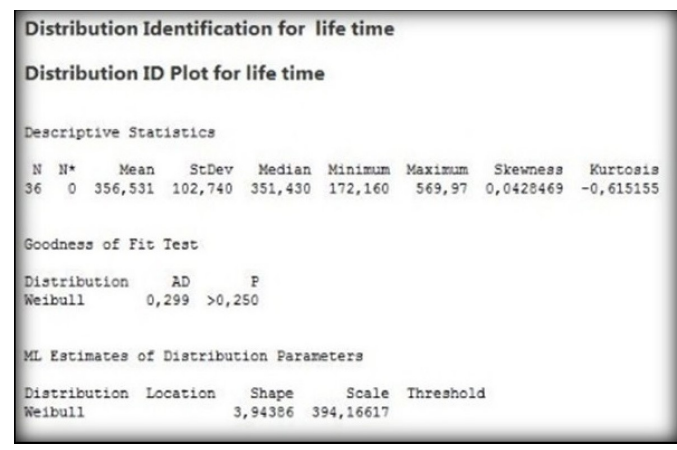

Figure 7. Distribution Plot of Life Time Data Identification on Liquid Waste Pump Machine 
The Goodness of Fit test is a test of the compatibility between the results of certain observations (frequency of observations) and the frequency obtained based on the expected value (theoretical frequency).

1) From the Weibull distribution above, it can be seen that the Goodness of Fit Test results in $A D=$ 0.299, the Anderson Darling Test is used to determine the distribution of the sample data (normally distributed data). The hypothesis of Anderson Darling is:

$\mathrm{H}_{0}=$ data follow a normal distribution

$\mathrm{H}_{1}=$ Data does not follow normal distribution with $5 \%$

Meanwhile, the decision-making theory on the Anderson Darling hypothesis is taken if $\mathrm{H}_{0} \geq p$ value $>\alpha$ and is rejected if $\mathrm{H}_{0} \geq p$-value $>\alpha$.

2) The results of the Weibull distribution on the Goodnes of Fit for $p$-value $>0,250$. Since the $p$ value of the Weibull distribution plot above is 0.250 for the Life Time data of the liquid waste pump machine, it is greater than the value of $\alpha$ (which is set at 0.05), it can be concluded that the Weibull distribution can be used as a representation of the data group. The representation here means that the data used can be accepted because the data used as a reference is in a concrete form.

From the identification distribution list for the Life Time data of the liquid waste pump machine, the output obtained is 36 , the Mean value is 356.531 , and deviation standard value is 102.740 . The value of the standard deviation is not too large, it shows that the diversity of the data is not too large, which means that the data is homogeneous (the characteristics are the same). The AD value of 0.299 , this value is relatively small, which means that $\mathrm{H}_{0}$ is accepted or the data is normally distributed, but from this $\mathrm{AD}$ value it cannot be decided with certainty whether the data is normally distributed or not because there are no definite parameters to determine that the data is normally distributed. Then there is a $p$-value $>0.250(>5 \%)$ the $p$-value means that $\mathrm{H}_{0}$ is accepted and $\mathrm{H}_{0}$ is stated that the data is normally distributed. After the value of the two parameters of the Weibull distribution $(\theta$ and $\beta) \theta$ is the scale parameter in the Weibull distribution with a value of 394.16617 and $\beta$ is the shape parameter of the Weibull distribution with a value of 3.94386. Then there is a median of 351.430 as the middle value of the processed data, the minimum value from the Minitab results is 172.160 and the maximum value from the data is 569.97. Skewness is the level of asymmetry of a distribution with a skewness result of 0.0428469 . Kurtosis with a result of -0.615155 , kurtosis (difficulty of data distribution) is a measure of the high and low peak of a distribution. After the values of the two parameters of the Weibull Distribution ( $\theta$ dan $\beta$ ) have been known, it is continued with calculations to obtain the CDF, reliability, failure rate and mean values for the Liquid Waste Pumping Machine.

1) Cumulatif Distribution Function

The Cumulative Distribution Function (CDF) for the Weibull Distribution is as follows:

$$
F(t)=1-e^{-\left(\frac{t}{\theta}\right)^{f}}
$$

It has been mentioned that the value of $\beta=3.94386$ and the value of the scale parameter $\theta=$ 394.16617. Researchers took the time to operate or live in, namely the average time of the liquid waste pump machine $=356.531$ hours. The CDF calculation is as follows:

$$
\begin{aligned}
& F(t)=1-e^{-\left(\frac{z}{6}\right)^{\beta}} \\
& F(t)=1-e^{-\left(\frac{856,551}{89416617}\right)^{8,94886}} \\
& \mathrm{~F}(\mathrm{t})=1-0.51 \\
& \mathrm{~F}(\mathrm{t})=0.49
\end{aligned}
$$

From the above CDF calculation, the value is 0.49 . Based on the CDF requirements, namely $0 \leq$ $\mathrm{F}(\mathrm{t}) \leq 1$, it means that the CDF value which is less than 1 or a value below half of 1 means that the device is still in normal condition.

2) Reliability

The reliability function for the Weibull Distribution. The equation is as follows: 


$$
R(t)=e^{-\left(\frac{t}{6}\right)^{\beta}}
$$

Where the value is stated that the value of $\beta=3.94386$ and the value of the scale parameter $\theta=$ 394.16617 .

$$
\begin{aligned}
& R(t)=e^{-\left(\frac{\mathrm{t}}{6}\right)^{\beta}} \\
& \mathrm{R}(\mathrm{t})=0.51
\end{aligned}
$$

The results show that the probability that the liquid waste pump machine can run or perform its functions for 356.531 hours is 0.51 .

\section{3) Failure Rate}

The failure rate (Hazard Rate) or the level of damage (Failure Rate) is a conditional probability of a component failing within the smallest interval of failure rates.

$$
\begin{aligned}
& h(\mathrm{t})=\frac{\beta}{\theta} \frac{t^{\beta-1}}{\theta} \\
& h(\mathrm{t})-\frac{3,94386}{394,16617} \frac{356,531}{394,16617} \\
& \mathrm{~h}(\mathrm{t})=0.01(0.7429) \\
& \mathrm{h}(\mathrm{t})=0.0074
\end{aligned}
$$

The average liquid waste pump engine life is up to 356,531 hours with a failure rate of 0.0074 .

4) Mean

The average of the Weibull distribution can live as follows:

$$
\begin{aligned}
& E(t)=\theta \Gamma\left(1+\frac{1}{\beta}\right) \\
& E(t)=394,16617 \Gamma\left(1+\frac{1}{3,94386}\right) \\
& \mathrm{E}(\mathrm{t})=357.27
\end{aligned}
$$

\begin{tabular}{|c|c|c|}
\hline Same Type of Damage & $\begin{array}{c}\text { Average } \\
\text { Repair Time }\end{array}$ & $\begin{array}{c}\text { Pump } \\
\text { Engine } \\
\text { Reliability }\end{array}$ \\
\hline Bearing & \multirow{11}{*}{5,82 hours } & \multirow{2}{*}{$\mathrm{CDF}=0,49$} \\
\hline Ball Valve & & \\
\hline Bolt Ring & & \multirow{3}{*}{$\begin{array}{c}\text { Reliability }= \\
0,51\end{array}$} \\
\hline Bolts and nuts & & \\
\hline Oil & & \\
\hline Glan Packing & & \multirow{3}{*}{$\begin{array}{c}\text { Failure Rate } \\
=0,0074\end{array}$} \\
\hline Shaft & & \\
\hline Mechanical seal for kew pump & & \\
\hline O-Ring & & \multirow{3}{*}{$\begin{array}{c}\text { Mean }= \\
357,27 \text { hours }\end{array}$} \\
\hline Pressure Gauge & & \\
\hline Wheel for transfer carriage & & \\
\hline
\end{tabular}

Based on the calculation of the average value above, which is 357.27 , it can be interpreted that the liquid waste pump machine can run for 357.27 hours.

\subsection{Liquid Sewage Pump Machine Analysis}

With the results of the calculations above, the discussion in the study obtained the length of time for handling damage with the Preventive Maintenance Method as shown in Table 6.

Table 6. Damage Handling Time 
While the comparison of costs used by using Repair Policy and Preventive Maintenance can be seen in the following Table 7.

Table 7. Expenditures

\begin{tabular}{|c|c|c|}
\hline Cost & TMC & $\mathrm{TCr}$ \\
\hline Repair Policy & $1 \operatorname{Rp} 357.046,-$ & Rp 357.046,- \\
\hline Method & $\mathrm{Rp} \mathrm{1.891,-}$ & Rp 1.891,- \\
\hline Total & $\mathrm{Rp} 1.317 .754,-$ & Rp 1.317.754,- \\
\hline Preventive Policy & Rp 333.944,- & Rp 153.689,- \\
\hline Method & Rp 4.506,- & $\mathrm{Rp} 0,-$ \\
\hline Total & $\operatorname{Rp~1.147.960,-}$ & Rp 364.142,- \\
\hline
\end{tabular}

\subsection{Company Regulation}

The regulations that can be used in carrying out the maintenance of the Liquid Waste Pump Machine so that it can work optimally can be seen in the table below.

From the Table 8, it can be concluded that with regulations on Liquid Waste Pumping Machines can reduce various damages that will occur in the future so that the pump machine will work optimally and can minimize the costs that will be incurred by the company for the liquid waste pump machine used in delivery of liquid waste as organic fertilizer for oil palm plantations.

Table 8. Regulation of Liquid Waste Pumping Machine

\begin{tabular}{|c|c|c|c|c|}
\hline No & Regulasi & \multicolumn{3}{|c|}{ Keterangan } \\
\hline 1 & $\begin{array}{l}\text { Periodic maintenance on the Liquid } \\
\text { Waste Pump Machine }\end{array}$ & \multicolumn{3}{|c|}{ maintenance is done once a month } \\
\hline 2 & $\begin{array}{l}\text { Maintenance of all components of the } \\
\text { Liquid Waste Pump Machine }\end{array}$ & \multicolumn{3}{|c|}{ Treatment is carried out in 1 cycle, which is 357.27 hours } \\
\hline \multirow{4}{*}{3} & \multirow{4}{*}{$\begin{array}{l}\text { Costs incurred in choosing a } \\
\text { treatment method }\end{array}$} & \multirow{2}{*}{ Repair Policy Method } & TMC & $\operatorname{Rp} 1.317 .754,-$ \\
\hline & & & $\mathrm{TCr}$ & Rp 1.317.754,- \\
\hline & & \multirow{2}{*}{$\begin{array}{c}\text { Preventive Maintenance } \\
\text { Method } \\
\end{array}$} & TMC & Rp 1.147.960,- \\
\hline & & & $\mathrm{TCr}$ & Rp 364.142,- \\
\hline 4 & Adding a filter to the pool & \multicolumn{3}{|c|}{$\begin{array}{l}\text { it is important to add a filter to the liquid waste pond so } \\
\text { that stones, leaves and husks do not enter the input pipe } \\
\text { so that they are not clogged }\end{array}$} \\
\hline
\end{tabular}

\section{Conclusion}

The conclusion of this research is how to control the causes of damage that occur in the liquid waste pump machine can be overcome by using the Preventive Maintenance Method within a period of 1 month and maintenance of every component in the liquid waste pump machine within 1 cycle, namely 357.27 hours with a repair time of 5.82 hours. Controlling other causes of damage is to add a filter to the liquid waste pool so that stones, leaves and liquid waste husks do not hinder the suction pipe of the liquid waste pump machine.

\section{References}

[1] R. Wardhani and Y. Rahadian, "Sustainability Strategy of Indonesian and Malaysian Palm Oil Industry: A Qualitative Analysis," Sustainability Accounting, Management and Policy Journal, vol. 12, no. 5, 2021.

[2] Y. Y. Tan, M. M. Bello, A. A. A. Raman, "Towards Cleaner Production In Palm Oil Industry: Advanced Treatment Of Biologically-Treated POME Using Palm Kernel Shell-Based Adsorbent," Cleaner Engineering and Technology, vol. 2, 2021. 
[3] M. Heriyanto, A. F. Febrian, F. K. Andini, T. Handoko, And D. Suryana, "Antecedents of Sustainable Competitive Advantages: A Case Study of Palm Oil Industries in Indonesia," The Journal of Asian Finance, Economics and Business, vol. 8, no. 2, pp. 911-921, Feb. 2021.

[4] Basiron, Yusof, and F. Shahidi. "Bailey's Industrial Oil and Fat Products," Edible Oil and Fat Products: Edible Oils, pp. 333-429, 2005.

[5] S. Iman, and Y. E. Widyastuti, Kelapa Sawit. Jakarta: Penebar Swadaya, 1992.

[6] Handoko amd Hanni. "Dasar- Dasar Manajemen Produksi dan Operasi. Jakarta: BPFE, 1977

[7] A. Sofjan, Manajemen Produksi dan Operasi, Edisi 4. Jakarta: Fakultas Ekonomi Universitas Indonesia, 1993.

[8] S. Assauri, 1998, Manajemen Produksi dan Operasi. Edisi Revisi 2008. Universitas Indonesia: Fakultas Ekonomi, 1998.

[9] B. S. Abbas, E. Steven, H. Christian and T. Sumanto, Penjadwalan Preventive Maintenace Mesin B.Flute Pada PT AMW Jurusan Teknik Industri. Fakultas Teknik, Jakarta: Universitas Bina Nusantara, 2009.

[10] Corder and Antony, Teknik Manajemen Pemeliharaan. Jakarta: Erlangga, 1966.

[11] Edword and Rakesh, Manajemen Operasi. Jakarta: Binarupa Aksara, 1966

[12] A. Jaoude, Forecasting in Mathematics: Recent Advances, New Perspectives and Applications. United Kingdom: IntechOpen, 2021.

[13] Smith and M. Anthony, Realibility Centered Maintenance. New York: McGraw-Hill Inc, 1933.

[14] V. Gaspersz, Analisis Sistem Terapan Berdasarkan Pendekatan Teknik Industri. Bandung: Tarsito, 1992.

[15] J. Bin, A. Mohamed, and K. Muduli, "Effect of Preventive Maintenance on Machine Reliability in a Beverage Packaging Plant," International Journal of System Dynamics Applications, vol. 10, no. 3, pp. 50-66, April 2021 